\title{
Spatial and frequency distributions of triclinisity of K-feldspar in augen gneisses and related granitic rocks in the Nepal Himalayas
}

\author{
Takashi Kano \\ Department of Earth Sciences, Yamaguchi University, 1677-1 Yoshida, Yamaguchi 753-8512, JAPAN \\ For correspondence, E-mail: kano@yamaguchi-u.ac.jp
}

Triclinicity (obliquity and/ or $\triangle$-value) has been well known as the mineralogical term indicating the ordering degree of K-feldspar, and defined as $\triangle=12.5$ (d13-1-d131) by Goldsmith and Laves (1954). Since then, it has been considered as a petrological indicator for the thermal history of granitic rocks. Thefactor controlling triclinicity in natural rocks is variableand different from case by case, but the most basic factors are the temperature of formation or thetemperature of recrystallization and cooling rate of the rocks and / or the influence of hydrothermal fluids (Parsons and Brown, 1984). The aim of this study is to obtain information for the thermal history of granitic rocks in the Himalayas from the frequency and spatial distributions of triclinicity. More than 600 grains of K-feldspar collected from different types of augen gneisses and related granitic rocks in the Nepal Himalayas were X-rayed by powder method in this study.

Mode of occurrence of granitic rocks carrying K-feldspar in the Himalayas

Granitic rocks carrying K-feldspar in the Himalayasare exposed mainlyin threezonesfrom north to south; thehigher Himalayas, the MCT zone and the Mahabharat Range (Ohta and Akiba, 1973). They have characteristic lithological nature in each. The occurrence of granitic rocks in the higher Himalayas is recognized in three types. One is tourmaline granites occurred in the High Himalayan Range intruding into both the Tibetan Tethys sediments and Himalayan gneisses. They form intrusive bodiesand/ or small veinletsin Himalayan gneisses. TheManaslu granite and Makalu granite are the typical examples of large intrusives (LeFort 1981). Thegranites havetypical S-typenature and considered to bethe product of crustal anatexis derived from basement gneisses at the Tertiary orogeny. The second type is the Himalayan gneiss its self. The neighbor of the tourmaline granites, the gneiss is highly migmatitic with rheomorphic appearanceconsisting of K-feldspar, plagioclase, biotite, garnet, kyaniteor sillimanaiteand tourmaline. Thethird typeisthehigher Himalayan augen gneiss, someof which includeremarkablylarge $\mathrm{K}$-feldspar singlecrystals reaching $50 \mathrm{~cm}$ in diameter.

Granitic rocks in the MCT-zone occur as augen gneiss too and are associated with mylonitic and cataclastic rocks. The augen gneiss in the MCT-zone is exposed in narrow bands of several 10 centimeters to several 10 meters in thickness intercalated concordantly in the low to middle grade metamorphic rocks derived from the Midland metasediments. Thezone of augen gneiss istraceablethrough wholeareasalong the MCT zone with swell and pinch structure. In the part of east and west Nepal Himalayas, the zone of augen gneiss form lenticular bodies of several kilometers thick. The outer part of the body is highly sheared into blastomylonitic, but porphyritic appearancestill remains in theinner core, and hence, theorigin of augen gneiss is defined as a porphyritic graniteintruded along the thrust sheet dipping low angle (Kano 1984). The Sheopuri zoneflinging thenorthern border of theKathmandu basin is the other intrusivezone of granitic and gneissic rocksassociated with augen gneiss.

Granitic rocks in the Mahabharat Range are exposed also in several lenticular bodies elongated in the $\mathrm{E}-\mathrm{W}$ direction (the general trend of the Mahabharatzone) with several to ten-several kilometersin short axis of thebody. This granitic body is generally composed of porphyritic graniteor partly massivegranite in the inner core, and is grade into augen gneiss to blastomylonite toward the outer part of thebody. These occurrences are similar to those of the augen gneiss in the MCT-zone, although the general dips of the elongated (flattened) body is high angle in the Mahabharat Range. The radiometric agse of these granitic bodies are, however, early Paleozoic, and do not indicate the Himalayan orogeny.

Measurement of triclinicity and 131 peak patterns

$\mathrm{K}$-feldspar in augen gneisses and porphyritic granites is separated by hand picking and examined in grain by grain. Powdered samplesareX-rayed using $\mathrm{Cu}-\mathrm{K} \alpha, 2 \theta=29^{\circ}$ to $31^{\circ}, 0.25^{\circ}$ $\mathrm{min}$. In most case, $\triangle$-value of $K$-feldspar could not be exactly determined due to the broad peak patterns of X-ray diffractions on the intermediate state, particularly in the case of RD (randomly disordered) feldspar. In this study, ten types of 131 peak patterns were used to describe the crystalline states of K-feldspar for triclinicity, namely from Type 1 indicated nearly $=0$ to Type 9 nearly maximum ordering with $\triangle=1.0$. The results of measurements are listed in histograms for several rock types in different regions.

Frequency distribution of triclinicity (131 peak patterns) of Kfeldspar

K-feldspar in higher Himalayan gneisses and granitic rocks including tourmaline granites has mostly high ordered peak patternsof maximum microcline $(\triangle=$ nearly 1.0), and orthoclase ( $\triangle$ =nearly 0 ) is subordinate or rather rare. K-feldspar of granitic and gneissic rocks in the Sheopuri zone shows a similar frequency distribution with that in thehigher Himalayan gneiss zone.

K-feldspar of augen gneisses in the MCT-zone is characteristic in occurrences of wide ranges of triclinicity from $\triangle=$ nearly 0 to nearly 1.0 , and particularly broad peak patterns indicating the intermediate state between orthoclase and maximum microcline. The broadness of X-ray diffraction is shown on a single grain in its self indicating the RD feldspar. In several examples, which are not rare, the coexistence of quite different states of feldspar grains is distinct even in a hand specimen, such as of $\Delta=0, \Delta=1.0, \Delta=0.5$ (intermediate microcline), RD feldspar and albite megacrysts in same size of K-feldspar. K-feldspar in the Maharabhat Range has also similar characteristics with those of the augen gneiss in the MCT-zone in the central Nepal Himalayas.

The frequency distribution of triclinicity is different from the area to area in the MCT-zone among the east, central and 
west Nepal Himalayas. The distribution in the east Nepal Himalayas is bimodal consisting of orthoclase and microcline, and rather predominated in orthoclase ( $\triangle=$ nearly 0$)$ than microcline. On the other hand, K-feldspar in the central Nepal Himalayas is most frequent in the intermediate microcline or RD feldspar. The distribution in thewest Nepal Himalayas is also similar with that in the east Nepal Himalayas (more predominated in intermediate type than in the east Nepal Himalayas).

Concluding remarks

Thespatial and frequency distributionsof K-feldspar crystalline stateestimated by X-ray diffraction patternsischaracteristic both in rock types and from the area to area. This may suggest the difference of cooling histories of granitic rocksin theHimalayas. There has been an expectation that recrystallization under deformation operate to transform K-feldspar to low microcline from high temperature state, but the results were quite unexpected.

The augen gneiss in the MCT-zone is a kind of sheared granite intruding along the thrust sheet, however, $\mathrm{K}$-feldspar is not always low microcline, but also it remains intermediate to rather high temperatureforms. This augen gneiss containsalbite megacrysts as an isolated mineral phase. Theseoccurrences may indicate that the granitic magma was comparatively low temperature at the intrusion (but higher than the orthoclase stable temperature), and then quickly solidified and cooled to remain high form. On the other hand, tourmaline granites and gneisses in the higher Himalayas, which are expected to carry high temperature type K-feldspar, are predominated in low microcline. This may betheresult of crystallization of K-feldspar under the influence of fluids and slower cooling than the MCT zone.

\section{References}

GoldsmithJR and F Laves. 1954. Themicrocline-sanidinestability relations. Geochim Cosmochim Acta 5: 1-19.

Kano T. 1984. Occurrences of augen gneisses in the Nepal Himalayas. J. Nepal Geol. Soc. Spec Vol 4: 121-139

LeFortP. 1981. Manaslu leucogranite: Acollision signature of the Himalayas, a model for its genesis and emplacement. J Geophys Res 86: 1054510568

Parsons I and WL Brown. 1984. Feldsparsand thethermal history of igneous rocks. In:WL Brown (ed), Feldsparsand feldspathoids, NATO ASI Series. 317-371

Ohta Y and C Akiba (ed) 1973. Geology of the Nepal Himalayas. Saikon shuppann, Tokyo. 286p 